\title{
A Study of Reliability and Validity for Citizenship Knowledge and Skill Scale
}

\author{
Mustafa Icen (iD) 1,*
}

${ }^{1}$ Social Studies Education, College of Education, Yildiz Technical University, Istanbul, Turkey,

\section{ARTICLE HISTORY}

Received: Jun 19, 2020

Revised: Oct. 23, 2020

Accepted: July 27, 2020

KEYWORDS

Citizenship,

Social studies,

Citizenship education,

Reliability,

Validity

\begin{abstract}
The study aims to develop a current scale that has a higher validity and reliability and reveals high school students' perceptions of measuring their citizenship knowledge and skills. The study was conducted with two different groups. The first group is the group where data is collected to conduct Exploratory Factor Analysis (EFA) and it consists of 258 students. The second group is the group where the data is collected to carry out Confirmatory Factor Analysis (CFA) and it consists of 180 students. A total of 438 students participated in the study providing different students were in both groups. As a result of the analyzes, it was determined that the Citizenship Knowledge and Skill Scale, which includes a total of 24 items, consists of a 5-factor structure. These factors are termed as "Participation in Social Life", "Right to Education", "Individual Duties", "Duties of the State" and "Common Rights". The total variance explained by the scale is $61.79 \%$. Additionally, there is a significant relationship between these 5 factors and there is no autocorrelation problem. Item-factor and item-test correlation coefficients were calculated for all items of the scale and it was determined that each item was consistent not only with the factor it contained but also with the whole test. Cronbach Alpha reliability of the general of Citizenship Knowledge and Skill Scale is 0.91 and Omega reliability is 0.92 . It can be said that the reliability and validity of the scale are applicable and high.
\end{abstract}

\section{INTRODUCTION}

Citizenship is defined in the Constitution of the Republic of Turkey as follows: "Everyone bound to the Turkish state through the bond of citizenship is a Turk. The child of a Turkish father or a Turkish mother is a Turk. 'Citizenship' is acquired under the conditions determined by the law and it is lost only in cases specified in the law." (Constitution of Republic of Turkey, art. 66).

Citizenship is not just a legal formula, it refers to a social and cultural phenomenon that is becoming more and more prominent (Brubaker, 2009). It is a social identity established on the axis of citizenship, freedoms and responsibilities and open to change and restructuring (Keyman, 2008; Brubaker, 2009) It is closely related to the concepts of citizenship and identity, democracy, freedom, human dignity, human rights and respect for human rights, social justice, solidarity, and cultural, moral, mental and physical development. Teaching these concepts to individuals and internalizing by them can only be achieved through citizenship education. For 
citizenship education approaches, it is necessary to consider and evaluate individual, society, family, and school together.

Transition to modern citizenship education in Turkey started in 1995 with the Ministry of Education's participation of the UN's “Decade of Human Rights Education" Project. It renamed the course of 'Citizenship Knowledge' as 'Citizenship and Human Rights' and revised the course content (Çayır \& Bağl1, 2011; Karaman-Kepenekçi, 2005).

In this context, Turkey has increased the importance given to citizenship education since 1995, and directed to changes and innovations in education for citizenship. The title of the "Citizenship Knowledge" course has been changed to "Citizenship and Human Rights Education". This course has been abolished with the 2005 curriculum and citizenship education has started to be taught within the topics of 'Social Studies' course.

Although a new course titled "Citizenship and Democracy Education" was put into the program in 2010, this course was also abolished with the $4+4+4$ education reform carried out in 2012 . In the curricula published in 2018, citizenship education is once again integrated into the social studies course. In the seven learning areas in the 2018 Social Studies Curriculum, especially the acquisitions related to citizenship education have been included (Ministry of National Education of Turkey, 2018). The abolition of "Citizenship and Democracy Education", which is taught as a separate course, has been criticized by citizenship educators and still continues to be discussed. Besides its providing individuals to acquire the knowledge, understanding, talent and values that are needed by daily life, citizenship education has an important place in individuals' internalizing democratic values and expressing themselves in society by emphasizing current issues such as human rights, world problems, providing intercultural solidarity and interaction.

It is pointed out that a good citizen is a person who knows both how to govern and to be governed, which means that free people are governed by free people. Aristoteles argued that middle-class citizens, whom he thought would be able to obey the system and the logic rules more easily and comfortably, could govern the state better. According to Aristoteles, the education system in a state should be the same for everyone, and the preparation of this system should be a public activity. A good education will create citizens who desire to do their best, and a livable life will take place when all citizens establish a real community (Johnson \& Morris, 2010).

Today, active and participative citizens, who are aware of global problems, are conscious about science and technology, take place in the process of preventing problems and finding solutions, and have more rights to speak in the administration process, are emphasized more and more.

The knowledge, skills and values that the countries put effort to gain to the students with the arrangements they have made in their curricula also reflect the characteristics of the citizen to be reached. Young people are hypothetically interested in ideological problems towards the future and feel the need to determine a political view or a social stance (Küçükkaragöz, 2009). On the other hand, when the European Fund 2014 Report is examined, it is determined that while participation in the politics increases in the European Union countries, there was no increase in it in Turkey and even decreased over time (Eurofound, 2014). Although the participation to the elections is higher in Turkey compared to the European Union (72\%) since $88 \%$ of its voters participated in the elections, it is stated that there is low participation in the decision-making process. It is also stated that political engagement that is dealt as actively participating in a political party or trade union meeting, participating in demonstrations and communicating politicians and related stakeholders is found as $7 \%$ in Turkey. And this is indicated as a very low level compared to European Union countries. 
It is seen that there are researches and measurement tools towards the level of secondary school students in 'Citizenship' course in Turkey. Citizenship education is a process that starts with preschool education and continues at all levels of education. Measuring the impact of citizenship education on students will be easier as the students move from the concrete process period to the abstract process period, their age increases and the students progress at the education level. For this reason, considering their development and learning levels, it is thought that performing the measurement of the knowledge and skills related to citizenship at the secondary education level will provide healthier and more comprehensible data. In this context, it was decided to develop a measurement tool in order to determine the citizenship knowledge and skills and perceptions of secondary school students who started to have citizenship education at the primary and secondary level.

The most obvious difference of the scale from the other scales previously developed in the literature (Doğanay, 2008; Doğanay \& Sar1, 2009; Sağlam, 2000) is that it was developed for high school students. This scale was developed on high school students, and it measures the characteristics of the individuals regarding their citizenship knowledge and skills. The scales previously developed in the literature were mostly related to secondary school students and in general, they were about how the individual perceived the concept of citizenship. So they were mostly at the conceptual level. Citizenship Knowledge and Skills Scale measures the reflections of citizenship education on the individual, that is if the individual has the knowledge and skills related to citizenship and her/his ability to use these knowledge-skills in her/his life.

\section{METHOD}

\subsection{Participants}

As the study aims to develop a scale for determining the citizenship perceptions of high school students, the study group consists of high school students. The study was conducted with two different groups. The first group is the group in which data is collected to perform Exploratory Factor Analysis (EFA). The second group is the group in which data is collected to perform Confirmatory Factor Analysis (CFA) to determine to what extent the determined factors are supported by the observed variables after performing EFA.

The first group consists of 258 students. 67 (26\%) of the students are males and 191 (74\%) of them are females. $9(3.5 \%)$ of the students stated that their mothers were illiterate, while 4 $(1.6 \%)$ of the students stated that their fathers were illiterate. The number of students indicating that their mothers are primary school graduates is $138(53.5 \%)$, and the number of students indicating that their fathers are primary school graduates is $75(29.1 \%)$. The number of students whose mothers are middle school graduates is $46(17.8 \%)$, and whose fathers are middle school graduates is $64(24.8 \%)$. The number of mothers had university-level education is $23(9 \%)$ and the number of fathers had university-level education is 46 (17.3). 131 (50.8) of the students are studying at Anatolian High School, 90 (34.9) of them at Vocational High School and 20 (7.8\%) of them are attending Science High School and the others are at Religious Vocational High School and other high schools.

The second group of students consists of different students than in the first group. It consists of 180 students, 50 of which $(27.8 \%)$ are males and $130(72.2 \%)$ of which are females. $78(43.3 \%)$ of these students were at Anatolian High School, 88 (48.9\%) were at Vocational High School, 8 (4.4\%) were at Science High School and others at Religious Vocational High School and other High Schools. $6(3.3 \%)$ of these students stated that their mothers are illiterate, while 2 $(1.1 \%)$ of the students stated that their fathers are illiterate. The number of students indicating that their mothers are primary school graduates is $57(31.7 \%)$, and the number of students indicating that their fathers are primary school graduates is $53(29.4 \%)$. The number of students whose mothers are middle school graduates is $50(27.1 \%)$, and the number of students whose 
fathers are middle school graduates is 48 (26.7\%). The number of mothers had university-level education is $19(10.6 \%)$, and the number of fathers had university-level education is $33(18.4 \%)$.

\subsection{Item Pool Preparation Process}

In order to determine the students' perception of citizenship, a literature review was conducted first. As a result of the examined literature (Doğanay, 2008; Doğanay \& Sarı, 2009; Durualp \& Doğan, 2017; Ersoy, 2014; İçen, Öztürk \& Y1lmaz, 2017; Morais \& Ogden, 2011; Sağlam, 2000; 2011; Şen, 2018; 2019; Uğurlu, 2011; Üstel, 2016), a total of 27 Items were prepared including the Right to Education (6 Items), the Individual's Duties toward the State (8 Items), the Social-Political Participation (5 Items), the Duties of the State toward the Citizen (5 Items)and the Citizen Identification (3 Items). Then, a 5-point Likert scale was prepared as $1=$ Strongly Disagree, $2=$ Disagree, $3=$ Undecided, 4= Agree, 5= Strongly Agree.

\subsection{Analysis Process}

The data obtained from the second and third samples were loaded and analyzed in SPSS 23.00 and Lisrel 8.7 software to perform validity and reliability analysis of the measuring device. In addition, SPSS 23.00 was used for Exploratory Factor Analysis and Lisrel 8.7 was used for Confirmatory Factor Analysis. SPSS 23.00 and JASP 0.9.0.1 (for OMEGA reliability) software were used for reliability analysis.

After the scale items were decided, firstly, whether the scale is comprehensible was presented to the expert opinion in terms of its scope. In the second step, 5 students were asked to answer the scale one by one by reading it aloud, so that its face validity was analyzed. In order to determine the factor structure of the scale, Exploratory Factor Analysis (EFA) based on Maximum Likelihood (ML) was performed using the data obtained from the first sample (Tezci, 2016; Colton \& Covert, 2007; Comrey \& Lee, 1992). However, in order to apply ML, the data must show a normal distribution (MacCallum, Browne \& Cai, 2007). For this reason, multivariate normality has been tested first. The reason for choosing this test was that it could be broadly generalized for situations where the data showed a normal distribution, larger correlations could be preferred, and the estimates produced less variability compared to other models were important factors (Briggs \& MacCallum, 2003; Fabrigar, Wegener, MacCallum \& Strahan, 1999). It is aimed to combine many interrelated measurements with typical structure or factors with factor analysis. Since factor analysis is based on the assumption that all variables are related to a certain extent (Kandemir, Tezci, Shelley \& Demirli, 2019), this analysis was carried out to determine the items that are not under any factor and are not related or have a overlapping structure.

Since it was aimed to determine the minimum number of factors suitable for the original data set, ML was used (Ford, McCallum \& Tait, 1986). Eigenvalue (since eigenvalue 1 and above will be significant for the factors) and scree graph were examined in determining factor numbers (Hair, Anderson, Tatham, \& Black, 1995). In addition, the "direct oblimin" technique, one of the oblique rotation techniques, was used in the study. The reason for using this technique is the expectation that there may be a correlation between dimensions, especially in behavioral science areas (Byrne, 2001; Williams, Onsman, \& Brown, 2020). Tabachnick \& Fidell (2001) suggested that oblique rotation should be preferred if there is no significant reason-justification and if there is a coefficient of 0.32 and above in the correlation matrix. Since factor loads met the practical significance value, the value of \pm 0.30 was used. The reason for using this value is its contribution to explaining the amount of the total variance calculated by a factor (Ho, 2006).

Confirmatory Factor Analysis (CFA) was performed using the data from the second sample. CFA was used to test the accuracy of the structure determined by EFA. CFA was performed in the Lisrel program with the maximum likelihood method. It was applied to test the factorial 
structure of the model determined by EFA (Ding, Velicer \& Harlow, 1995; Gomez \& Fisher, 2003). A series of indices were used to evaluate the fit of the model. Since $x^{2}$ index is affected by sampling size, it is evaluated together with the degress of freedom. Apart from this, even though the values of CFI (comparative fit index), GFI (goodness of fit index), NFI (Normed Fit Index), NNFI (Non-Normed Fit Index) are demanded to be close to 1, the value of 0.90 and above can be accepted (Bentler \& Bonett, 1980). Even so, Hu and Bentler (1999) stated that these values' being in 0.95 and above indicates a good fit. RMSEA (root mean square error of approximation) indicates that the value which is 0.08 or below is sufficient but 0.06 indicates a better fit (Hu \& Bentler, 1999).

For the convergent validity of the scale, the analysis of the Explained Common Variance (ECV) values of each factor was determined by comparing the correlation of each factor with each other (Fornell \& Larcker, 1981). Discriminant validity was evaluated by comparing the square root value of the variance explained with the square of correlations between factors. Convergence and distinctive validity is another type of validity used in testing and verifying the established model (Fornell \& Larcker, 1981; Malhotra, 2011). Cronbach Alpha, Omega Reliability and Combined Reliability were calculated for reliability analysis. Composite Reliability (CR) is used to measure the internal consistency of factors and the value of 0.70 and above is considered as a good value (Hair, Black, Babin \& Anderson, 2010). In the context of internal consistency, Cronbach Alpha analysis is not considered sufficient in case of multiple factor structures. It is also recommended to calculate the Omega Reliability coefficient (Dunn, Baguley \& Brunsden, 2014).

\section{FINDINGS}

\subsection{Face Validity}

In order to determine whether the prepared scale items are suitable for measuring the knowledge, skills and perceptions about citizenship, 5 experts working in the social studies, citizenship education, Turkish literature and measurement fields were first presented for their opinions. As a result of the feedbacks received from the experts, it is determined that there is no need for any correction and a statement to be added. The scale form was then submitted to the opinion of 3 experts in the field of measurement and evaluation. Expressions were asked to audit in terms of scale.

As a result of this inspection, no correction was required. Then, before applying the scale, 4 different students were asked to read and answer the scale items aloud by applying face to face. Thus, it was checked whether there was any item that could not be understood or cause misunderstanding. As a result of the application, it was determined that the scale items were understandable and the data collection phase was started.

\subsection{Suitability of the Data for Analysis}

The first group consists of a total of 258. Descriptive analysis was conducted for the suitability of the data obtained from these students for analysis. Before applying the exploratory factor analysis, it was decided whether ML should be applied or not by examining the missing value, multicollinearity, linearity and multivariate normality in the data (Çokluk, Şekercioğlu, \& Büyüköztürk, 2014). Mahalanobis' $D^{2}$, Cooks distance values for multivariate outliers were examined (Stevens, 1984). "Normality among single variables is assessed by skewness and kurtosis" (Tabachnick \& Fidell, 2001, p. 613). When P-P plots, Q-Q plots, skewness and kurtosis, Mahalanobis' $D^{2}$ and Cooks ditance values were examined, it was observed that the data showed normal distribution, so ML method was applied. Whether there are extreme values, skewness and kurtosis values were examined. As a result of the descriptive analysis, it was observed that the general average of the scale was $2.94(S D=.56)$, the Item with the lowest 
average $($ Mean $=2.56, S D=1.39)$ was Item 6 , and the item with the highest average $($ Mean $=$ $3.51, S D=1.23$ ) was Item 10. It was observed that the skewness value ranged from 0.416 to 0.448 , and the kurtosis value ranged from -0.686 to -1.273 (in the interval of \pm 1.5 ). The EFA suitability of the measurements, in other words, the sampling adequacy and the test of sphericity analysis (Kaiser-Mayer-Olkin [KMO] and Bartlett 'Test) were examined to determine whether the number of samples allowed for sufficient factorization. At the end of the analysis, $\mathrm{KMO}=$ 0.844 was determined. This value indicates that it is a good value since it is above .700 , and the sample is large enough for analysis. Bartlett test (Approx. $x^{2}=3130.576, d f=351, p=.000$ ) was observed to be significant.

In the correlation analysis, the relationship between binary and partial correlations and variables was tested. The highest binary correlation $(r=.78, p<.05)$ was observed to be between Item 6 and Item $10(r=-.001, p>.05)$ and the lowest correlation was between Item 25 and Item 16. The highest binary correlation of Item $25(r=.22)$ was observed with Item 26 and the binary correlation with other Items was observed to have been low. Similarly, the binary and partial correlations of Item 9 were observed to be very low. Correlations between the items under the factors with each other were examined. It is determined whether there is data with outliers. In addition, the Variance Inflation Factor has been tested that there is no multicollinearity between variables

\subsection{Analysis of Factor Structure}

Different ways can be followed to determine the factor structure of the scale. One of the commonly used approaches is the Scree Plot and the other one is to select factors with an eigenvalue above 1. In addition, the other approaches are Velicer's (1976) Minimum Average Partial Test (MAP) and Horn's (1965) Parallel Analysis. The Scree-Test) was proposed by Cattell (1978). Thompson (2004) reported that this method was criticized because, in this method, the graphic is based on the visual reading. In addition, there are opinions about the Scree plot in the data set obtained from large samples is more appropriate (Zwick \& Velicer, 1986). Selection of eigenvalues greater than 1 as a factor (Kline, 1994; Tabachnick \& Fidel, 2001). In this method, both of them evaluated the factor structure for reasons such as containing some sample errors, sometimes more than the number of factors (Thompson, 2004; Velicer \& Jackson, 1990; Zwick \& Velicer, 1986). The Scree-test is presented in Figure 1.

As seen in the Scree plot, the scale was evaluated to have 5-factor structures. There were 7 factors with an eigenvalue above 1 . However, Items 25 and 9 were observed to create a separate factor. Maccallum, Widaman, Zhang and Hong (1999) suggested that the number of Items in a factor should be 3 or more for the beneficial factor. Therefore, when the factors consisting of a single Item were ignored, it was observed that it had 5-factor structures. It was also evaluated that the factor structures obtained were significant (Tatlidil, 1992). 


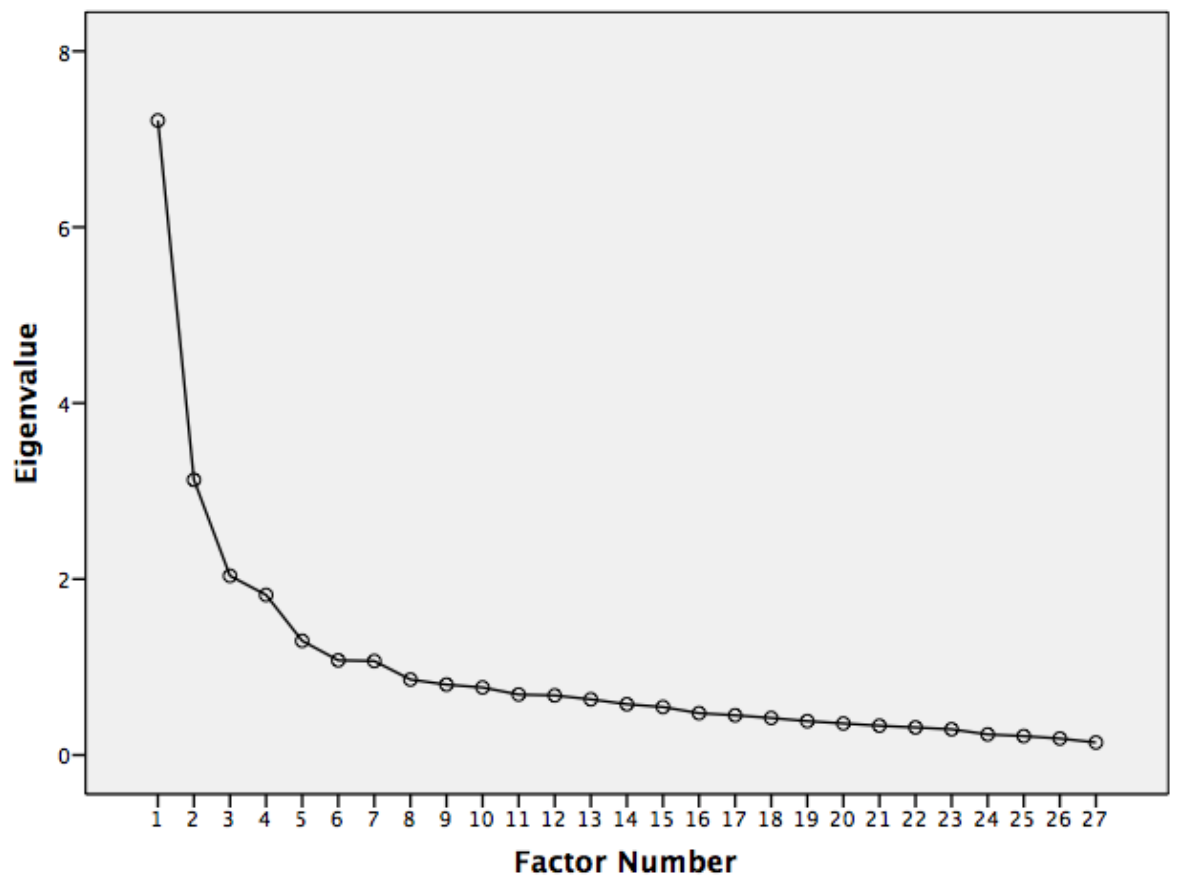

Figure 1. Scree-Test

Parallel analysis approach and MAP test have been determined to have had similar results in many studies (e.g. O'Connor, 2000; Yavuz \& Doğan, 2015; Zwick \& Velicer, 1986). In this study, the number of factors was determined by using Syntax written by O'Connor (2000). As a result of the analysis, Average Partial Correlations results are given in Table 1.

Table 1. Eigenvalues Regarding Partial Correlations Obtained from the MAP Test

\begin{tabular}{lllllllll}
\hline & Squared & Power4 & & Squared & Power4 & & Squared & Power4 \\
\hline 0 & .0734 & .0152 & 9 & .0278 & .0026 & 18 & .0985 & .0301 \\
1 & .0280 & .0029 & 10 & .0320 & .0035 & 19 & .1161 & .0381 \\
2 & .0230 & .0014 & 11 & .0376 & .0050 & 20 & .1352 & .0527 \\
3 & .0211 & .0012 & 12 & .0431 & .0060 & 21 & .1699 & .0749 \\
4 & .0178 & .0011 & 13 & .0491 & .0079 & 22 & .2330 & .1128 \\
5 & .0165 & .0010 & 14 & .0541 & .0100 & 23 & .3008 & .1698 \\
6 & .0195 & .0015 & 15 & .0604 & .0145 & 24 & .3315 & .2088 \\
7 & .0216 & .0019 & 26 & .0709 & .0172 & 25 & .4912 & .3773 \\
8 & .0250 & .0025 & 17 & .0836 & .0235 & 26 & 1.0000 & 1.0000 \\
\hline
\end{tabular}

As a result of the analysis, it was observed that the smallest average squared partial correlation was .0165 and this value was in the 5th step. It was determined that the fourth power of the partial correlation took place in the 5 th step. The fourth power of the partial correlation was included in the program by O'Conner (2000). At this point, the scree-test, eigenvalue and MAP analysis were evaluated together and the number of factors was decided.

\subsection{Exploratory Factor Analysis}

In determining the construct validity of the scale, EFA was performed first. As a result of the ML analysis based on the data obtained from a total of 27-item scale obtained from 258 students, it was observed that the factor load has a 5 -factor-structure which is greater than \pm 0.30 and its eigenvalue is greater than 1 . However, Item 25 which includes the definition of citizenship (Being Turkish requires being a Muslim) and Item 9 related to individual rights (Individuals should have the right to express their racist ideas as well) were excluded from the scale. Item 14 (I am thinking of joining a political party in the future) was also excluded from 
the scale since it was placed under two factors (Its load in Factor $1=0.340$, lts load in Factor $4=.406)$. The factor loads of the scale Items and the total variance explained and factors are given in Table 2.

Table 2. Factor Loads of the Scale Items and Factors that They are Distributed

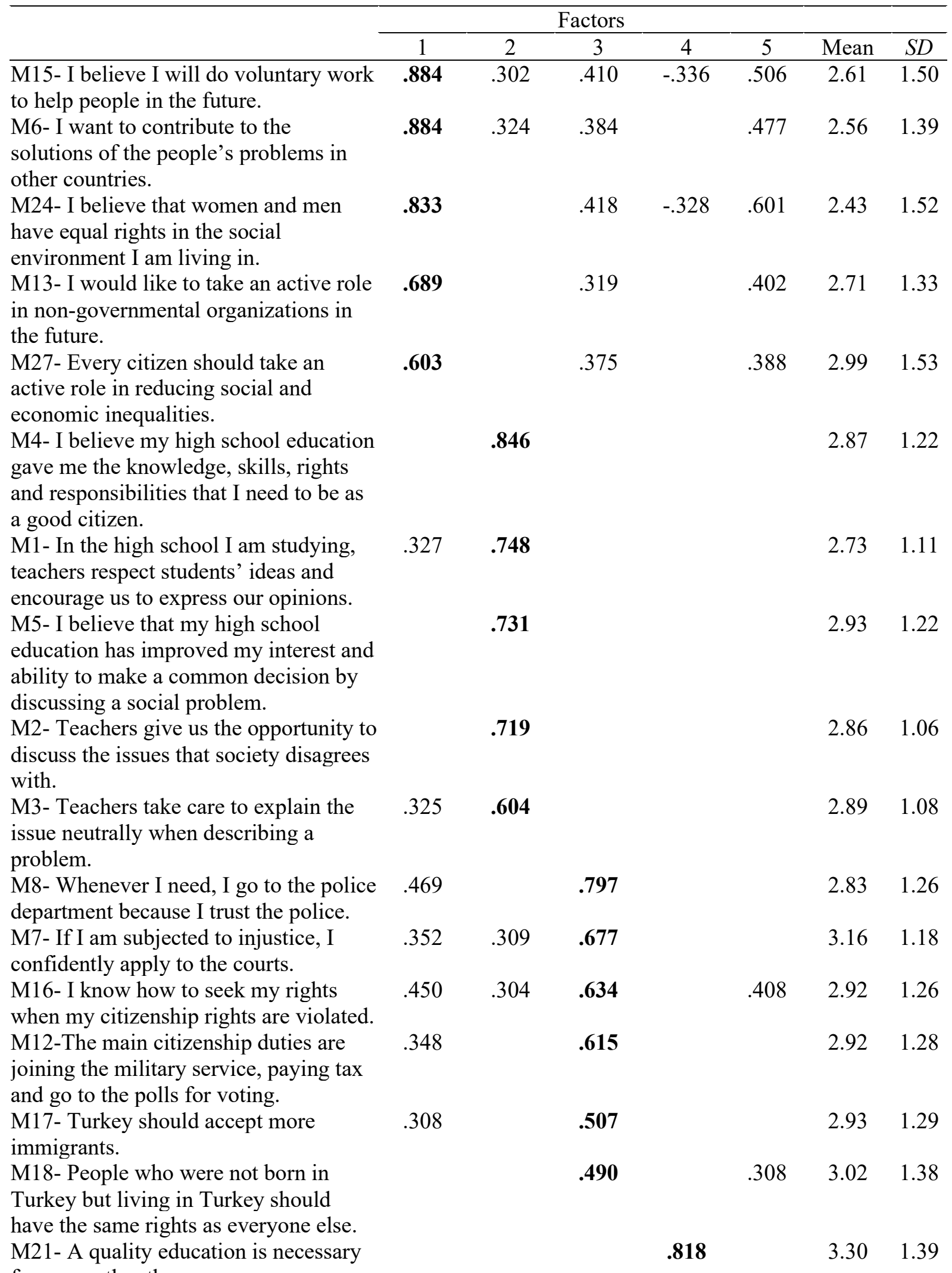

for men rather than women. 
M20- People who were not born in

Turkey but living in Turkey must learn

Turkish.

M26- "Turkish Nation" is the common

name of all citizens living in our

country.

M10- Although a law violates human

rights, people must obey that law.

M19- If there are not enough jobs to

employ everyone, men should be

employed more than women.

M23- State officials should not be

allowed to display their (religious,

ethnic and sectarian identities) at work.

M11-Citizens should be able to

organize peaceful protests when they

.339

$\mathbf{8 0 3} 2.81$

1.44

find necessary.

M22- The state should provide enough

financial support to the unemployed to

maintain their lives.

Total Variance Explained

$27.986 \% \quad 10.791 \% \quad 5.428 \% \quad 4.636 \% \quad 3.432 \%$

*Unvalidated translation. The scale was developed in Turkish. In order to use it in different languages, it should be re-evaluated in terms of its realiability and validity, again.

As a result of EFA, a total of 5 factor structures were determined. Factor 1 is named as "Participation in Social Life" since it contains items related to duties in individual's social life. There are 5 items under this factor. The item with the highest factor load is Item 6 and 8 with 0.884 , and the item with the lowest factor load is Item 27 with 0.603 . The contribution of these items to the total variance is $27.986 \%$. The second factor is relevant to the perception of citizenship regarding education. For this reason, this factor has been named as "Right to Education". There are also 5 items in this factor. The total explained variance is $10.791 \%$. The Item with the highest factor load is Item 4 with 0.846 . And the item with the lowest factor load is Item 3 with 0.604 . The third factor contains 6 items and the total explained variance is $5.428 \%$. The Items under this factor are named as 'Individual Duties' since they include the citizenship duties toward the state. In this factor, the highest factor load is Item 8 with 0.797 , and the lowest factor load is Item 18 with 0.490 . There are 4 Items in the fourth factor and the total explained variance is $4.636 \%$. The Items here reflect the notion of the social state. For this reason, it was named as "Duties of the State". The highest factor load belongs to Item 21 with 0.813 , while the Item with the lowest factor load is Item 10 with 0.451 . Factor 5 consists of 4 items. The contribution of this factor to variance is $3.432 \%$. Since the items under this factor concern common rights, they are named as "Individual Rights". The highest factor load belongs to Item 19 with 0.803 and the lowest factor load belongs to Item 22 with 0.622 . The total variance explained by the scale is $52.273 \%$. It is seen that the factor load of some items is under more than one factor. For example, the factor load of Item 15 under Factor 1 is 0.884 and the load under Factor 5 is .506. Similarly, although Item 24 is under two factors, its factor loads under two factors are above .100 . Therefore, it was decided that it was under the factor with a high factor load. 


\subsection{Descriptive Analysis Results}

The second group consists of 180 students. The data obtained from these students were used in CFA, convergence validity and discriminant validity analyses. Descriptive analysis results of the data obtained from these students are given in Table 3.

Table 3. Descriptive Analysis Results for the Second Group

\begin{tabular}{lcccccc}
\hline & Minimum & Maximum & Mean & $S D$ & Skewness & Kurtosis \\
\hline 1- Right to Education & 1,00 & 5.00 & 3.09 & .89 & -.080 & -.405 \\
2- Participation in Social Life & 1.00 & 5.00 & 2.92 & 1.13 & .084 & -1.107 \\
3- Individual Duties & 1.00 & 5.00 & 3.07 & .93 & .093 & -.899 \\
4- Duties of the State & 1.00 & 5.00 & 3.07 & .95 & -.049 & -.804 \\
5- Common Citizenship & 1,00 & 5.00 & 3.33 & .99 & -.145 & -.819 \\
Rights & 1.55 & 4.72 & 3.09 & .69 & .132 & -.821 \\
General & & & & & & \\
\hline
\end{tabular}

As a result of the analysis, it was observed that the average of the scale was $3.09(S D=.69)$. In the analysis made in terms of sub-dimensions (factors), the lowest average (Mean=2.92, $S D=$ 1.13 ) is in the second factor, the 'Participation in Social Life', and the highest average (Mean $=3.33, S D=.99$ ) is in the 'Common Citizenship Rights.' It was observed that the Skewness and Kurtosis values of the scores obtained from the scale were within the interval of \pm 1.5 .

\subsection{CFA Analysis Results}

CFA analysis was applied to the data obtained from the second sample group to which the scale was applied and the suitability of the structure determined in EFA was tested. Jöreskog (1969) suggested that EFA will generally be used to determine the construct validity of the scales. As a result of the CFA analysis applied to the data obtained from 180 students, $x^{2} / d f$ ratio was determined as $(608.40 / 242)=2.51$. In addition, some fit indices $(\mathrm{RMSEA}=0.088, \mathrm{RMR}=.12)$ were observed to be higher than they should be, while others were observed lower than they should be $(\mathrm{NFI}=0.92, \mathrm{RFI}=0.91, \mathrm{GFI}=0.80, \mathrm{AGFI}=0.75)$. Schreiber, Nora, Stage, Barlow, and King (2006) stated that it is not necessary to reconstruct the theoretical model if a sufficient fit index is achieved with the proposed modifications. For this reason, the proposed fit indices were examined. Eventually, as a result of the correction of the error variances of some variables, fit indices were obtained within acceptable limits. As a result of the modification made by based on the 4 error variances applied in the Education, Individual Duty, Common Rights factors, the ratio of $x^{2} / d f$ was found as $(441.05 / 238)=1.85$ between the items of 4 and 5 in the 'Education' factor; between the Items of 8 and 18 in the 'Individual Duty' factor, and between the items of 20 and 21 and items of 10 and 21 in the 'Common Rights' factor. Although the value was excellent, other fit indices were also examined since it is affected by the sample size. According to this, the values of RMSEA $=0.066$; NFI $=.94, \mathrm{NNFI}=0.96, \mathrm{CFI}=0.97$, IFI $=.97$; RMR $=$ 0.09; $\mathrm{SRMR}=0.07$, GFI $=0.84$ AGFI $=0.80$ were determined. Some of the values $\left(x^{2} / d f\right.$, NNFI, CFI and IFI) were excellent, some of them (NFI, RMR, SRMR, RMSEA) were acceptable, while others (GFI and AGFI) were observed to be low (Hair et al., 1998; Hoyle, 1995). A sufficient fit index was obtained with the proposed fit indices. The Path Analysis Diagram obtained as a result of the analysis is given in Figure 2. 


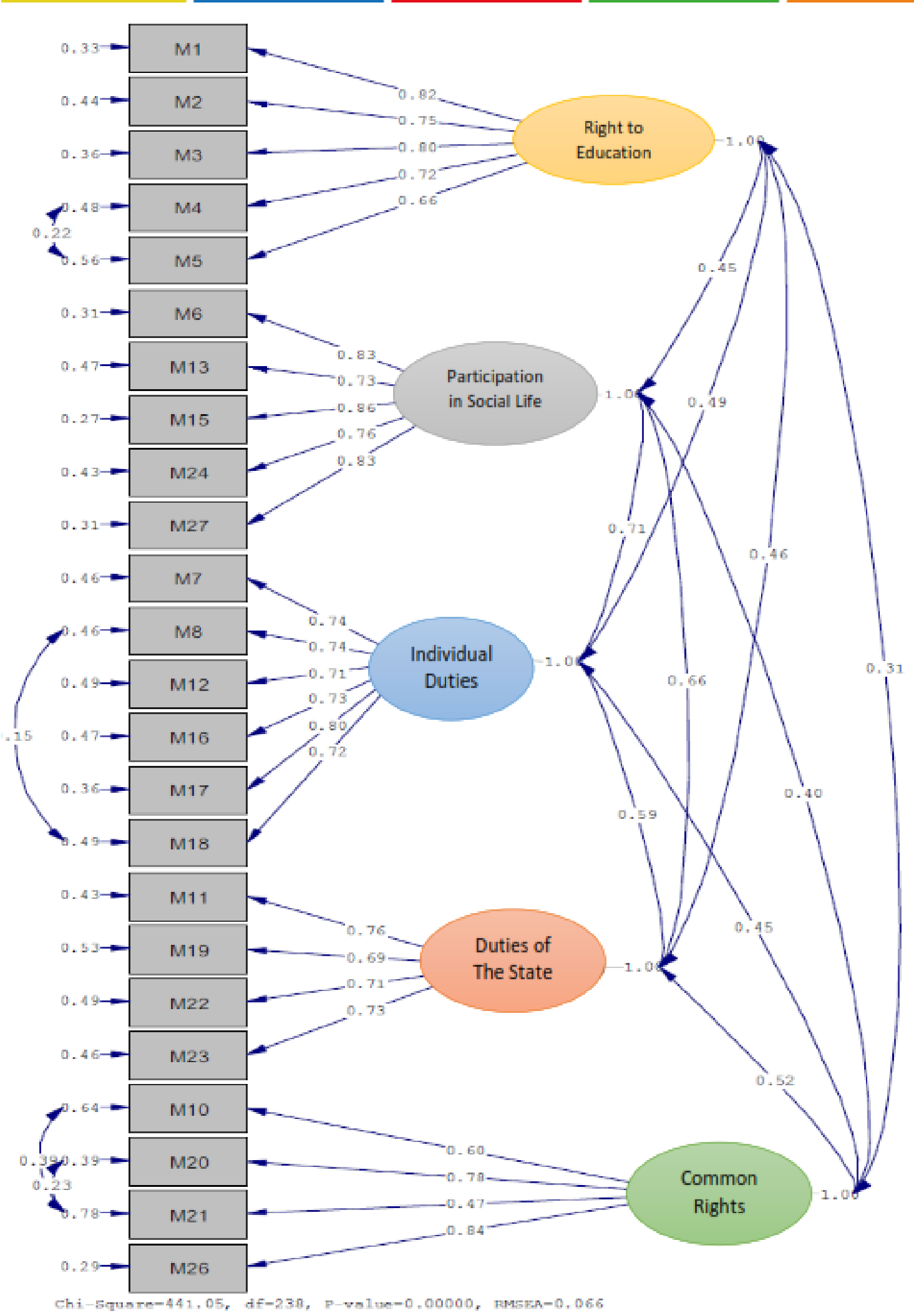

Figure 2. Standardized path analysis diagram

As a result of the modification made between a total of four items, it was seen that the indexes reached a level that could be called "good". In addition, no significant change was observed in the explained factor loads of these items, except for the $21^{\text {st }}$ item. The factor load of the $21^{\text {st }}$ item decreased from .70 to .47 . However, since this value is above .30 (Harrington, 2009), it is 
at an acceptable level. It was determined that this item with the lowest load value was significant $(t=6.20, p<.05)$. As given in the Path Analysis diagram, the paths drawn for implicit variables from all observed variables were found to be significant. When the path coefficients are analyzed, it was determined that the lowest load belongs to Item 21 (0.47) in 'Common Citizenship Rights' factor, and the highest load belongs to Item 15 in 'Participation in Social Life' Factor. Ford, McCallum and Tait (1986) suggested factor loadings in social sciences to be above 0.40 . Factor load values of all items ranged from 0.47 to 0.86 . In addition, it was observed that the correlations between the implicit variables were positive and that the highest correlation was between 'Individual Duties' and 'Participation in Social Life' (0.71) and that the lowest correlation (0.31) was between 'Common Citizenship Rights' and 'Right to Education.' And there was no correlation above 0.85 and the correlations were significant (Bryne, 2001).

\subsection{Corvergent and Discriminant Validity}

Although CFA is used for construct validity, Campbell and Fiske (1959) also recommended to examine the convergence and discriminant validity to determine the 'structure' of a measuring tool. Convergence validity is the degree of confidence of the feature, which is measured well by its indicators, while the discriminant validity is the degree of measuring different features that are unrelated to each other. Or it is the relationship between observed variables that measure kthe latent variable. The discriminant validity is used to determine whether the observed variables are representative of the latent structures to which they belong to (Hair, et al., 2010). According to the Fornell-Larcker (1981) criterion, it is widely used in CFA to evaluate the degree of common variance shared among the implicit variables of the model. According to this criterion, convergent validty of the measurement model can be evaluated with Average Variance Extracted [AVE] and Combined Reliability (CR-Composite Reliability [CR]). Acceptable value of CR is 0.70 and above and acceptable value of AVE is 0.70 and above, but 0.50 and above is sufficient. In addition, the CR value should be greater than the AVE value (Gouveia \& Soares, 2015; Raykov, 1997). On the other hand, the square root of the AVE value should be greater than the correlation values between the latent variables (Bagozzi \& Yi, 1988; Hair et al., 2010; Hu \& Bentler, 1999). The Maximum Shared Variance (MSV) and Average Shared Variance (ASV) values were examined for the discriminant validity. AVE $>$ MSV and AVE $>$ ASV criteria determined by Hair et al. (2010) were taken into consideration for the for the discriminant validity.

Construct validity of whether or not the citizenship scale measures the structure to which it is directed was tried to be determined by using discriminant validity, which is a version of a) convergent validity and b) divergent validity. Average Variance Extracted (AVE) and Combined Reliability (CR) values are presented in Table 4.

Table 4. Correlations between AVE, CR Values and Factors

\begin{tabular}{llllllllll}
\hline & AVE & CR & MSV & ASV & 1 & 2 & 3 & 4 & 5 \\
\hline 1- Rights to Education & .57 & .87 & .24 & .19 & $\mathbf{( . 7 6 )}$ & & & & \\
2- Participation in Social Life & .65 & .90 & .50 & .33 & .45 & $\mathbf{( . 8 1 )}$ & & & \\
3- Individual Duties & .55 & .88 & .50 & .32 & .49 & .71 & $\mathbf{( . 7 4 )}$ & & \\
4- Duties of the State & .52 & .81 & .44 & .36 & .46 & .66 & .59 & $\mathbf{( . 7 2 )}$ & \\
5- Common Citizenship Rights & .48 & .78 & .27 & .18 & .31 & .40 & .45 & .52 & $\mathbf{( . 6 9 )}$ \\
\hline
\end{tabular}

The fact that the factor loadings and AVE values of the scale are greater than .50 is a proof of the convergence validity of that measuring tool. However, if CR values are .70 and above, it is sufficient that ASV value is 0.40 and above (Formel \& Larcker, 1981; Peterson, 2000). The fact that ASV values of the scale show that 0.50 and CR are above 0.70 shows that it has 
convergence validity. Although the ASV value for Common Citizenship Rights is 0.48 , this value is at an acceptable level considering that $\mathrm{CR}$ coefficient is .78. For the discriminant validity, the Formel and Larcker (1981) criteria was used. Accordingly, the correlation coefficients between the square root of the ASV value and each structure in each row-column were examined. Accordingly, the correlation between each structure is lower than the square root of the ASV value. Also, MSV and ASV values in all sub-factors are lower than the ASV value. This shows that it contributes to the positive discrimination of the measurement model. The results can be said that each structure measures different features.

\subsection{Cronbach Alpha and Omega Reliability}

The reliability of the data obtained from the measurement tool in terms of internal consistency was tested with the Cronbach Alpha coefficient. In addition, Omega Reliability (Zinbarg, Yovel, Revelle \& McDonald, 2006) value, which is a recommended reliability in multi-factor scales and when factor loads are not equal, was calculated and compared with Cronbach Alpha Coefficient. Analysis results are presented in Table 5.

Table 5. Cronbach Alpha and Omega Reliability

\begin{tabular}{lcccccc}
\hline & $\begin{array}{c}\text { Alpha for } \\
\mathrm{N}=258\end{array}$ & $\begin{array}{c}\text { Alpha for } \\
\mathrm{N}=180\end{array}$ & $\begin{array}{c}\text { Alpha for } \\
\mathrm{N}=438\end{array}$ & $\begin{array}{c}\text { Omega for } \\
\mathrm{N}=258\end{array}$ & $\begin{array}{c}\text { Omega for } \\
\mathrm{N}=180\end{array}$ & $\begin{array}{c}\text { Omega for } \\
\mathrm{N}=438\end{array}$ \\
\hline Rights to Education & .85 & .87 & .84 & .85 & .87 & .85 \\
Participation in Social & .85 & .89 & .86 & .86 & .89 & .86 \\
Life & & & & & & \\
Individual Duties & .78 & .85 & .78 & .79 & .85 & .79 \\
Duties of the State & .81 & .86 & .73 & .81 & .86 & .74 \\
Common Citizenship & .70 & .84 & .67 & .69 & .84 & .68 \\
Rights & & & & & & \\
\hline
\end{tabular}

As a result of the analysis, Cronbach Alpha reliability and Omega Reliability are high for each sub-factor of the data obtained from the first sample. However, in the 'Common Citizenship Rights' factor, both Alpha (.67) and Omega Reliability coefficients (.68) of the 438-person group, in which both the first and second sample groups were evaluated together, were found lower than the others. Cronbach Alpha reliability of the overall scale is 0.91 and Omega reliability is 0.92 .

\subsection{Item-Discrimination and Item-Total Correlations}

As a result of the analysis regarding item-total correlations, the lowest correlation $(r=.41)$ in 'Right to Education' factor belongs to Item 2 and the highest correlation $(r=.55)$ belongs to Item 1. The lowest correlation $(r=.56)$ in 'Participation in Social Life' factor belongs to Item 13 and the highest correlation $(r=.67)$ belongs to Item 6 . The lowest correlation $(r=.54)$ of 'Individual Duties' belongs to Item 12, and the highest correlation $(r=.60)$ of it belongs to Item 16. The lowest correlation $(r=.47)$ in 'Duties of the State' factor is Item 19 and the highest correlation $(r=.67)$ of it belongs to Item 17. In the 'Common Citizenship Rights' factor, the lowest correlation $(r=.18)$ belongs to Item 21 and the highest correlation $(r=.53)$ of it belongs to Item 26.

In order to determine the discrimination of the sub-factors of each item and the overall scale, a comparison was made with the upper-lower group-27\% technique. As a result of the analysis, the lowest $t$ value $(t=3.988, p<.05)$ belongs to Item 23 and the highest $t$ value $(t=15.818, p$ $<.05$ ) belongs to Item 9 . It has been observed that there is a significant difference between the upper and lower groups for all items. 


\subsection{Correlation between Scale Factors}

In order to determine the relationship between the sub-dimensions of the scale, correlation analysis was performed. The results of the analysis are presented in Table 6.

Table 6. Correlation Analysis between Scale Dimensions

\begin{tabular}{|c|c|c|c|c|c|}
\hline & $\begin{array}{l}\text { Rights to } \\
\text { Education }\end{array}$ & Social Life & $\begin{array}{l}\text { Individual } \\
\text { Duties }\end{array}$ & $\begin{array}{l}\text { Duties of the } \\
\text { State }\end{array}$ & $\begin{array}{c}\text { Individual } \\
\text { Rights }\end{array}$ \\
\hline Rights to Education & 1 & & & & \\
\hline Social Life & $.379^{* *}$ & 1 & & & \\
\hline Individual Duties & $.402^{* *}$ & $.627^{* *}$ & 1 & & \\
\hline Duties of the State & $.376^{* *}$ & $.564^{* *}$ & $.487^{* *}$ & 1 & \\
\hline Individual Rights & $.217^{* *}$ & $.214^{*}$ & $.241^{* *}$ & $.313^{* *}$ & 1 \\
\hline $\begin{array}{l}\text { Citizenship Knowledge and Skills } \\
\text { Scale General Avg. }\end{array}$ & $.644^{* *}$ & $.796^{* *}$ & $.778^{* *}$ & $.775^{* *}$ & $.541^{* *}$ \\
\hline
\end{tabular}

As a result of the correlation analysis between the sub-dimensions of the scale, it was observed that the lowest correlation $(r=.21, p<.05)$ was between Social Life and Individual Rights $(r=.63, p<.01)$ and the highest correlation was between Social Life and Individual Duties. The lowest correlation between the general average of the scale and the sub-dimensions $(\mathrm{r}=.54$, $p<.01)$ is between Individual Rights and the highest correlation $(r=.80, p<.01)$ is between Social Life.

\section{DISCUSSION and CONCLUSION}

A scale with the aim of determining the citizenship knowledge and skills of secondary school students in Turkey have been developed. In the study, statistical analyses of the validity and reliability of this scale, which is expected to contribute to the citizenship education literature, is included.

For the validity and reliability study of the Citizenship Knowledge and Skills Scale, high school students studying in public schools in Istanbul were selected by simple random sampling method. In order to determine the psychometric properties of the scale, Exploratory Factor Analysis (EFA), Confirmatory Factor Analysis (CFA), content validity, construct validity and statistical analyzes such as internal consistency analysis and Cronbach Alpha calculations were included. As a result of the analyzes, it was determined that the Citizenship Knowledge and Skill Scale, which includes a total of 24 items, consists of a 5-factor structure. The first factor is named as "Participation in Social Life" because it contains items related to duties in social life. There are 5 items under this factor.

The contribution of these items to the total variance is $27.986 \%$. The second factor concerns the perception of citizenship regarding education. For this reason, this factor has been termed as "Right to Education". There are also 5 items in this factor. The total variance explained is $10.791 \%$. The third factor contains 6 items and the total variance explained is $5.428 \%$. The items under this factor are termed as "Individual Duties" since they include citizenship duties toward the state. There are 4 items in the fourth factor and the total variance explained is $4.636 \%$. The items here reflect the notion of the social state. For this reason, it was termed as "Duties of the State". The fifth factor consists of 4 items and total variance explanined is $3.432 \%$. The items under this factor are expressed as "Common Rights" since they concern general rights. The total variance explained by the scale is $52.273 \%$. Cronbach Alpha reliability 
of the general of Citizenship Knowledge and Skill Scale is 0.91 and its Omega reliability is 0.92 . It can be said that the reliability and validity of the scale are applicable and high.

The developed scale can be applied to secondary school (high school) students in order to measure their citizenship knowledge, skills and perceptions. However, if it is considered to be appropriate for the students' levels after taking an expert opinion, it can be used at other education levels to measure the students' citizenship knowledge and skills.

It should be noted that in this study, the numbers of samples were low. Specially, the number of data collected for Confirmatory Factor Analysis (CFA) was also low. Therefore, the measurement invariance could not be discussed. In order to discuss the measurement invariance, it should be tested in terms of gender and other variables. It can be done by increasing the numbers of samples. It is also useful to test the data by increasing the number of data in terms of different demographic data.

\section{Declaration of Conflicting Interests and Ethics}

The authors declare no conflict of interest. This research study complies with research publishing ethics. The scientific and legal responsibility for manuscripts published in IJATE belongs to the author(s).

\section{ORCID}

\section{Mustafa İçen (D) https://orcid.org/0000-0002-3289-6097}

\section{REFERENCES}

Bagozzi, R. P., \& Yi, Y. (1988). On the evaluation of structural equation models. Journal of the Academy of Marketing Science, 16 (Spring), 74-94.

Bentler, P. M., \& Bonett, D. G. (1980). Significance tests and goodness of fit in the analysis of covariance structures. Psychological Bulletin, 88, 588-606. https://doi.org/10.1037/0033 $\underline{-2909.88 .3 .588}$

Brubaker, R. (2009). Fransa ve Almanya'da vatandaşlık ve ulus ruhu (V. Pekel, Çev.). Ankara: Dost Kitabevi.

Briggs, N.E., \& MacCallum. R.C. (2003). Recovery of weak common factors by Maximum Likelihood and Ordinary Least Squares Estimation. Multivariate Behavioral Research. $38(1) .25-56$.

Bryne, B. M. (2001), Structural equation modeling with AMOS Mahwah, NJ: Lawrence Erlbaum Associates.

Campbell, D. T., \& Fiske, D. W. (1959). Convergent and discriminant validation by the multitrait-multimethod matrix. Psychological Bulletin, 56(2), 81-105.

Cattell, R. B. (1978). The scientific use of factor analysis in behavioral and life sciences. New York: Plenum.

Çokluk, Ö., Şekercioğlu, G., \& Büyüköztürk, Ş. (2014). Sosyal bilimler için çok değişkenli istatistik: SPSS ve LISREL Ankara: Pegem Akademi.

Colton, D., \& Covert, R. (2007). Designing and constructing instruments for social research and evaluation. San Francisco, CA: Jossey-Bass.

Comrey, A.L. \& Lee, H. B. (1992). A first course in factor analysis. Hillsdale, NJ: Erlbaum.

Çayır, K., \& Bağlı, M. T. (2011). 'No-one respects them anyway': secondary school students' perceptions of human rights education in Turkey. Intercultural Education, 22(1), 1-14.

Ding, L., Velicer, W. F. \& Harlow, L. L. (1995). Effects of estimation methods, number indicators per factor, and improper solutions on structural equation modeling fit indices. Structural Equation Modeling, 2, 119-144. https://doi.org/10.1080/1070551950 $\underline{9540000}$ 
Doğanay, A. (2008). What does democracy mean to 14-year-old turkish children? A Comparison with Results of the 1999 IEA Civic Education Study. Research Papers in Education, 25(1), 51-71.

Doğanay, A., \& Sarı, M. (2009). Lise öğrencilerinin vatandaşlık algılarına etki eden faktörlerin analizi [Analysis of the factors affecting high school students' perception of citizenship]. In A. Şişman, İ. Acun, C. Balkır, C. Yücel, H. Busher, T. Lawson, C. Wilkins, ..., H. Ermiş (Eds.), 1st International European Union, Democracy, Citizenship and Citizenship Education (p. 36-51). Uşak: Uşak University European Union Research Center.

Dunn, T. J., Baguley, T., \& Brunsden, V. (2014). From alpha to omega: A Practical solution to the pervasive problem of internal consistency estimation. British Journal of Psychology, 105, 399-412. https://doi.org/10.1111/bjop.12046

Durualp, E. \& Doğan, İ. (2017). Vatandaşlık algısı ölçeği'nin faktör yapısının incelenmesi. International Journal of Social Science, Number: 62, p. 65-83. http://dx.doi.org/10.9761 JASSS7173

Ersoy, A. F. (2014). Active and democratic citizenship education and its challenges in social studies classroom. Eurasian Journal of Educational Research, 55, 1-20.

Eurofound (2014). Quality of the life trends in Turkey: 2003-2012. Luxemburg: Publications Office of the European Union.

Fabrigar, L.R., Wegener, D.T., MacCallum, R.C., \& Strahan, E.J. (1999). Evaluating the use of exploratory factor analysis in psychological research. Psychological Methods, 4(3), 272299

Ford, J. K., McCallum, R. S. \& Tait, M. (1986). The application of exploratory factor analysis in applied psychology: A critical review and analysis. Personnel Psychology, 39, 291314.

Fornell, C. \& Larcker, D. F. (1981). Evaluating structural equation models with unobservable variables and measurement error. Journal of Marketing Research, 18(1), 39-50.

Gomez, R., \& Fisher, J. W. (2003). Domains of spiritual well-being and development and validation of the Spiritual Well-Being Questionnaire. Personality and Individual Differences, 35(8), 1975-1991. https://doi.org/10.1016/S0191-8869(03)00045-X

Gouveia, V. V., \& Soares, A. K. S. (2015). Calculadoras de validade de construto (CVC). João Pessoa, PB: BNCS/ Universidade Federal da Paraíba, [Construct Validity Calculators $(C V C)]$ Retrieved from http://akssoares.com/psicometria/calculadora-vme$\underline{\mathrm{e}-\mathrm{cc}}$

Hair, J. F., Anderson, R. E., Tatham, R. L., \& Black, W. C. (1995). Multivariate data analysis with readings, (4 th ed.), Englewood Cliffs, NJ: Prentice-Hall.

Hair, J. F., Black, W. C., Babin, B. J., Anderson, R. E., \& Tatham, R. L. (1998). Multivariate data analysis. Upper Saddle River, NJ: Prentice hall.

Hair, J.F., Black, W., Babin, B., \& Anderson, R. (2010). Multivariate data analysis (7th ed.). Upper Saddle River, NJ: Prentice-Hall.

Harrington, D. (2009). Confirmatory factor analysis. Oxford university press.

Ho, R. (2006). Handbook of univariate and multivariate data analysis and interpretation with SPSS. NY: Chapman and Hall/CRC.

Hoyle, R. H., (1995). The structural equation modeling approach: Basic concepts and fundamental issues. In R. H. Hoyle (Ed.), Structural equation modeling: Concepts issues and applications (pp. 1-15). Thousand Oaks, CA: Sage.

Horn, J. L. (1965). A rationale and test for the number of factors in factor analysis. Psychometrika, 30(2), 179-185.

Hu, L. T., \& Bentler, P. M. (1999). Cut-off criteria for fit indexes in covariance structure analysis: Conventional criteria versus new alternatives. Structural Equation Modeling, 6, 1-55. https://doi.org/10.1080/10705519909540118 
İçen, M., Öztürk, C., \& Yılmaz, A. (2017). Vatandaşlık duygusu ölçeği güvenirlik ve geçerlik çalışması. Uluslararası Alan Eğitimi Dergisi, 3(2), 26-36.

Johnson, L., \& Morris, P. (2010). Towards a framework for critical citizenship education. The Curriculum Journal, 21(1), 77-96. https://doi.org/10.1080/09585170903560444

Jöreskog, K. G. (1969). A general approach to confirmatory maximum likelihood factor analysis. Psychometrika, 34(2), 183-202.

Kandemir, M. A., Tezci, E., Shelley, M., \& Demirli, C. (2019). Measurement of creative teaching in mathematics class. Creativity Research Journal, 31(3), 1-12. https://doi.org/ $\underline{10.1080 / 10400419.2019 .1641677}$

Karaman-Kepenekçi, Y. (2005). A study of effectiveness of human rights education in Turkey. Journal of Peace Education, 2(1), 39-55.

Keyman, F. (2008). Kimlik, vatandaşllk ve demokratikleşme: Türkiye örneği. İstanbul: Osmanlı Bankası Arşiv ve Araştırma Merkezi Yayınları.

Kline, P. (1994). An easy guide to factor analysis. New York: Routledge.

Küçükkaragöz, H. (2009). Bilişsel gelişim ve dil gelişimi (Cognitive development and language development). In B. Yeşilyaprak (Ed.), Gelişim ve Öğrenme Psikolojisi (Development and Learning Psychology) (s.75-107). Ankara: Pegem Akademi Yayınları.

MacCallum, R. C., Browne, M. W., \& Cai, L. (2007). Factor analysis models as approximations. In R. Cudeck \& R. C. MacCallum (Eds.). Factor analysis at 100: Historical developments and future directions (pp.153-175). Mahwah. NJ: Lawrence Erlbaum Associates. Publishers.

MacCallum, R. C., Widaman, K. F., Zhang, S., \& Hong, S. (1999). Sample size in factor analysis. Psychological Methods, 4(1), 84-99. https://doi.org/10.1037/1082-989x.4.1.84

Malhotra, N. K. (2011). Pesquisa de Marketing: uma orientação aplicada, (6th ed.) São Paulo: Bookman.

Mardia, K. V. (1970). Measures of multivariate skewness and kurtosis with applications. Biometrika. 57, 519-530.

Ministry of National Education of Turkey. (2018). Sosyal bilgiler dersi öğretim programı (ilkokul ve ortaokul 4, 5, 6 ve 7. sinıflar) [Social studies curriculum (primary and middle school 4, 5, 6, and 7 grades)]. Ankara: MEB Devlet Kitaplar1. Retrieved from http://mu fredat.meb.gov.tr/Programlar.aspx

Morais, D. B., \& Ogden, A. C. (2011). Initial development and validation of the global citizenship scale. Journal of studies in international education, 15(5), 445-466.

O'Connor, B. P. (2000). SPSS and SAS programs for determining the number of components using parallel analysis and Velicer's MAP test. Behavior Research Methods, Instrumentation, and Computers, 32, 396-402.

Peterson, R. A. (2000). A meta-analysis of variance accounted for and factor loadings in exploratory factor analysis. Marketing letters, 11(3), 261-275.

Raykov, T. (1997). Estimation of composite reliability for congeneric measures. Applied Psychological Measurement, 21(2), 173-184.

Sağlam, H. İ. (2000). Sosyal bilgiler dersinin demokratik tutum geliştirmedeki rolü. Milli Eğitim Dergisi, 146, 67-71.

Sağlam, H. İ. (2011). Öğretmen adaylarının etkili vatandaşlık yeterlik düzeyleri. Kastamonu Ë̆itim Dergisi, 19(1), 39-50.

Schreiber, J. B., Nora, A., Stage, F. K., Barlow, E. A., \& King, J. (2006). Reporting structural equation modeling and confirmatory factor analysis results: A review. The Journal of Educational Research, 99(6), 323-38.

Stevens, J.P. (1984). Outliers and influential data points in regression analysis. Psychological Bulletin, 95, 334-344. 
Şen, A. (2018). Militarisation of citizenship education curriculum in Turkey. Journal of Peace Education, 16(1), 1-26. https://doi.org/10.1080/17400201.2018.1481019

Şen, A. (2019). Vatandaşlık eğitiminde değişiklik ve süreklilikler: 2018 sosyal bilgiler öğretim programı nasıl bir vatandaşlık eğitimi öngörüyor? (Changes and continuities in citizenship education: what kind of citizenship education does the 2018 social studies programme of study envisage?) Eğitimde Nitel Araştırmalar Dergisi, 7(1), 1-28. https://doi.org/10.14689/issn.2148-2624.1.7c1s.1m

Tabachnick, B. G., \& Fidel, L. S. (2001). Using Multivariate Statistics. Boston, MA: Allyn and Bacon.

Tatlıdil, H. (1992). Uygulamalı çok değişkenli istatistik (Applied multivariate statistics). Ankara: Akademi Publishing.

Tezci, E. (2016). Ĕ̆itimde ölçme ve değerlendirme (Measurement and evaluation in education). Ankara: Detay Publishing.

Thompson, B. (2004). Explaratory and Confirmatory Factor Analysis: Understanding Concepts and Applications. Washington: American Psychological Association.

Uğurlu, C. T. (2011). Citizeinship education in European Union countries and Turkey. Electronic Journal of Social Sciences, 10(37), 153-169.

Üstel, F. (2016). Makbul vatandaşın peşinde II. Meşrutiyet'ten bugüne vatandaşlık eğitimi (In pursuit of the acceptable citizen citizenship education since the II. Constitutional Monarchy) (7th ed.). İstanbul: İletişim Publishing.

Velicer, W. F. (1976). Determining the number of components from the matrix of partial correlations. Psychometrika, 41, 321-327.

Velicer, W. F., \& Jackson, D. N. (1990). Component analysis versus common factor analysis: Some issues in selecting an appropriate procedure. Multivariate Behavioral Research, 25, $1-28$.

Williams, B., Onsman, A., \& Brown, T. (2020). Exploratory factor analysis: A five step guide for novices. Journal of Emergency Primary Health Care, 8(3), 1-13.

Yavuz, G., \& Doğan, N. (2015). Boyut sayısı belirlemede Velicer'in map testi ve Horn'un paralel analizinin kullanılması. Hacettepe University Journal of Education, 30(3), 176188.

Zinbarg, R. E., Yovel, I., Revelle, W., \& McDonald, R. P. (2006). Estimating generalizability to a latent variable common to all of a scale's indicators: A comparison of estimators for wh. Applied Psychological Measurement, 30(2), 121-144.

Zwick, W. R., \& Velicer, W. F. (1986). Comparison of five rules for determining the number of components to retain. Psychological Bulletin, 99, 432-442. 


\section{APPENDIX}

\section{Citizenship Knowledge and Skill Scale}

\section{PARTICIPATION IN SOCIAL LIFE (First Factor-5 item)}

\begin{tabular}{|l|l|}
\hline 6 & I want to contribute to the solutions of the people's problems in other countries.. \\
\hline 13 & I would like to take an active role in non-governmental organizations in the future. \\
\hline 15 & I believe I will do voluntary work to help people in the future. \\
\hline 24 & I believe that women and men have equal rights in the social environment I live in. \\
\hline 27 & Every citizen should take an active role in reducing social and economic inequalities. \\
\hline
\end{tabular}

\section{RIGHT TO EDUCATION (Second Factor-5 item)}

\begin{tabular}{|l|l|}
\hline 1 & $\begin{array}{l}\text { In the high school I study, teachers respect students' ideas and encourage us to express our } \\
\text { opinions. }\end{array}$ \\
\hline 2 & Teachers give us the opportunity to discuss the issues that society disagrees with. \\
\hline 3 & Teachers take care to explain the issue neutrally when describing a problem. \\
\hline 4 & $\begin{array}{l}\text { I believe that my high school education gave me the knowledge, skills, rights and responsibilities } \\
\text { that I need to be as a good citizen. }\end{array}$ \\
\hline 5 & $\begin{array}{l}\text { I believe that my high school education has improved my interest and ability to make a common } \\
\text { decision by discussing a social problem. }\end{array}$ \\
\hline
\end{tabular}

INDIVIDUAL DUTIES (Third Factor-6 item)

\begin{tabular}{|l|l|}
\hline 7 & If I am subjected to injustice, I confidently apply to the courts. \\
\hline 8 & Whenever I need, I go to the police department because I trust the police. \\
\hline 12 & The basic citizenship duties are joining the military service, paying taxes and voting. \\
\hline 16 & I know how to seek my rights when my citizenship rights are violated. \\
\hline 17 & Turkey should accept more immigrants. \\
\hline 18 & $\begin{array}{l}\text { People who were not born in Turkey but living in Turkey should have the same rights as } \\
\text { everyone else. }\end{array}$ \\
\hline
\end{tabular}

DUTIES OF THE STATE (Fourth Factor-4 item)

\begin{tabular}{|l|l|}
\hline 11 & Citizens should be able to organize peaceful protests when they find necessary. \\
\hline 19 & If there are not enough jobs to employ everyone, men should be employed more than women. \\
\hline 22 & The state should provide enough financial support to the unemployed to maintain their lives. \\
\hline 23 & $\begin{array}{l}\text { State officials should not be allowed to display their (religious, ethnic and sectarian identities) } \\
\text { at work. }\end{array}$ \\
\hline
\end{tabular}

COMMON RIGHTS (Fifth Factor-4 item)

\begin{tabular}{|l|l|}
\hline 10 & Although a law violates human rights, people must obey that law. \\
\hline 20 & People who were not born in Turkey but living in Turkey must learn Turkish. \\
\hline 21 & A quality education is necessary for men rather than women. \\
\hline 26 & "Turkish Nation" is the common name of all citizens living in our country. \\
\hline
\end{tabular}




\section{Vatandaşlık Bilgi ve Beceri Ölçeği (Turkish)}

TOPLUMSAL HAYATA KATILIM (Birinci Faktör-5 madde)

\begin{tabular}{|l|l|}
\hline 6 & Diğer ülkelerdeki insanların sorunlarının çözümüne katkı sunmak istiyorum. \\
\hline 13 & Gelecekte sivil toplum örgütlerinde aktif rol almayı isterim. \\
\hline 15 & Gelecekte insanlara yardım etmek için gönüllü işler yapacağımı düşünüyorum. \\
\hline 24 & Yaşadığım sosyal çevrede kadın ve erkeklerin eşit haklara sahip olduğunu düşünüyorum. \\
\hline 27 & Her vatandaş, sosyal ve ekonomik eşitsizlikleri azaltmak için aktif rol üstlenmelidir. \\
\hline
\end{tabular}

EĞİTİM HAKKI (İkinci Faktör-5 madde)

\begin{tabular}{|l|l|}
\hline 1 & $\begin{array}{l}\text { Okuduğum lisede öğretmenler öğrencilerin fikirlerine saygı göstererek fikirlerimizi ifade etme } \\
\text { konusunda bizleri cesaretlendirirler. }\end{array}$ \\
\hline 2 & Öğretmenler, toplumun görüş ayrılığına düştüğ̈̈ konuları tartışmamıza firsat verirler. \\
\hline 3 & Öğretmenler, bir sorunu anlatırken konuyu tarafsı olarak anlatmaya özen gösterirler. \\
\hline 4 & $\begin{array}{l}\text { Lise eğitimimin iyi bir vatandaş olmam için gereken bilgi, beceri, hak ve sorumlulukları bana } \\
\text { sunduğunu düşünüyorum. }\end{array}$ \\
\hline 5 & $\begin{array}{l}\text { Lise eğitimimin toplumsal bir sorunu tartışarak ortak bir karar verme konusunda ilgi ve } \\
\text { yeteneğimi geliştirdiğini düşünüyorum. }\end{array}$ \\
\hline
\end{tabular}

BİREYSEL GÖREVLER (Üçüncü Faktör-6 madde)

\begin{tabular}{|l|l|}
\hline 7 & Bir haksızlığa uğrarsam, mahkemelere güvenle başvururum. \\
\hline 8 & İhtiyaç duyduğum zaman emniyet teşkilatına başvururum çünkü polise güvenirim. \\
\hline 12 & Temel vatandaşlık görevleri, askere gitmek, vergi vermek ve oy kullanmaktır. \\
\hline 16 & Vatandaşlık haklarım ihlal edildiği zaman haklarımı nasıl arayacağımı biliyorum. \\
\hline 17 & Türkiye daha fazla göçmen kabul etmemelidir. \\
\hline 18 & Türkiye'de doğmamış fakat Türkiye'de yaşayan kişiler herkesle aynı haklara sahip olmalıdır. \\
\hline
\end{tabular}

DEVLETIN GÖREVİ (Dördüncü Faktör-4 madde)

\begin{tabular}{|l|l|}
\hline 11 & Vatandaşlar gerekli gördüklerinde barışçıl protesto gösterileri düzenleyebilmelidir. \\
\hline 19 & Herkesi istihdam edecek kadar iş yok ise erkekler, kadınlardan daha çok işe alınmalıdır. \\
\hline 22 & Devlet, işsizlere hayatlarını sürdürmeye yetecek kadar maddi destek sağlamalıdır. \\
\hline 23 & $\begin{array}{l}\text { Devlet görevlilerinin farklı kimlikleri (dinsel, etnik ve mezhepsel kimliklerini) iş yerinde } \\
\text { sergilemesine müsaade edilmemelidir. }\end{array}$ \\
\hline
\end{tabular}

GENEL HAKLAR (Beşinci Faktör-4 madde)

\begin{tabular}{|l|l|}
\hline 10 & Bir yasa, insan haklarını ihlal etse de insanlar o yasaya uymak zorundadır. \\
\hline 20 & Türkiye'de doğmamış fakat Türkiye'de yaşayan kişiler Türkçe öğrenmek zorundadır. \\
\hline 21 & Kaliteli bir eğitim, kadınlardan çok erkekler için gereklidir. \\
\hline 26 & "Türk Milleti” ülkemizde yaşayan tüm vatandaşların ortak adıdır. \\
\hline
\end{tabular}

